\title{
Italian academic pedagogical magazines in the history of education in the $X X$ century
}

\author{
Simonetta Polenghi \\ Università Cattolica del Sacro Cuore, Milano
}

This paper aims to reconstruct the main strands of Italian educational thought using academic pedagogical magazines as a mirror for scientific and political developments through the years. I shall follow a chronological order, indicating the main changes which have occurred in Italy since its unification, concentrating on cultural turns and academic shifts. Pedagogical and school magazines have been the object of quite a number of extensive historical works, followed by other studies on school and educational publishing houses. Giorgio Chiosso has been the leading figure in this research for many years, having directed national projects in pedagogical journals and publishing houses, which have provided important historical tools, such as the catalogues of Italian school and educational magazines 1820-1945 (Chiosso, 1989, 1992, 1993, 1997) and the catalogues of Italian pedagogical publishing houses in the XIX and XX centuries (Chiosso, 2003a, 2008). Whilst the pedagogical magazines before and after unification have been carefully catalogued, the educational journals of Republican Italy have yet to be researched. An updated short biography and bibliography of the quoted educationalists can be found in the recent biographical dictionary directed by Chiosso and Sani (2013).

I. THE ORIGINS OF ITALIAN

SCHOOL MAGAZINES IN THE

FIRST DECADES AFTER

UNIFICATION (1861-1900)

$\mathrm{P}$ EDAGOGICAL JOURNALS already existed before unification. Some of them played a significant role in the pedagogical debate, such as Guida dell'educatore [The Educa- tor's Guide](1836-45), edited in Tuscany by the liberal Catholic educationalistRaffaello Lambruschini, a leading figure in Italian pedagogy; or the Piedmontese L'educatore primario [Elementary school teacher], later L'educatore [The educator] (1845-48), which discussed schooling and educational policy and represented a group of followers of the Lombard Ferrante Aporti, including Giovanni Antonio Rayneri. 
Following a reorganization as Giornale della Società d'istruzione e d'educazione [Journal of the Society for schooling and education] (1848-52), it went on to become the long-standing L'istitutore [The tutor] (1852-94) directed by Domenico Berti and Giovanni Lanza, which could boast the collaboration of important educationalists, such as Niccolò Tommaseo. This journal, from 1845, was the mouthpiece of the liberal Catholic wing, which favoured a united Italy under the control of the monarchy of Savoy (Romano, 1925; Chiosso, 1989, 1997). After unification (1861), with the freedom of the press granted by the Piedmontese Constitution of 1848 extended to the other regions, pedagogical and school journals were established throughout the entire peninsula.

These magazines were written by teachers, headmasters, school inspectors, educationalists including some famous ones like Giuseppe Sacchi, editor of Patria e famiglia [Fatherland and family] (Milan, 1861-73) (Chiosso, 1997, pp. 484-485), but not by professors.Their aim was to ameliorate teachers' practice and also to defend their economic rights. The editorial and publishing hubs were Turin, Florence, Milan (already notable pedagogical centres, with important publishing houses) and, after 1870, Rome. One has to remember that Turin, capital of the Kingdom of Sardinia, was the capital of Italy up until 1864, with Florence then becoming the capital until Rome was conquered in 1870. The growing self-awareness of teachers as a professional class favou- red the gradual growth of magazines of teachers' associations at the end of the century (86 in 1880-1900). As most authors and editors were adherents of Positivism, their magazines were an expression of an homogeneous cultural trend, which also aimed to diffuse the values of patriotism. (Chiosso, 1988b. pp. 1136-7.).

After unification, the chair of Pedagogy (previously established in Habsburg-ruled Padua and Pavia and since 1847 in Turin with Rayneri) was set up in other Universities, within the Faculty of Arts. It was always linked with Philosophy and held a minor academic position. The new professors of pedagogy were philosophers (hardly ever Catholic and mostly Positivist), like Roberto Ardigò in Padua and Andrea Angiulli in Naples.In Pavia and subsequently in Rome the Herbartian Luigi Credaro taught. The position of Italian chairs offers many similarities to Wolfgang Brezinka's picture of academic chairs in the Habsburg Empire (Brezinka, 2000-2014).

Due to the political situation, Catholic pedagogy was long excluded from the universities, with some exceptions like Turin, where the tradition survived thanks to Giuseppe Allievo. The cultural and political opposition between Church and State, worsened after Rome's capture, drew papal Catholics away from the State schools. Fierce argument raged around schools where religion was omitted and around a school system that did not recognize private and therefore Catholic schools, whose final certificates had no legal value (Palom- 
$b a, 2008)$. Catholic magazines like La libertà d'insegnamento [Freedom of teaching] (Bergamo 1879-84) and Fede e scuola [Faith and school] (Brescia 1892-1904) vehemently opposed the school policy of the time. The authoritative Jesuit Journal La civiltà Cattolica (1850-present day) dedicated space to questions of education and schooling.In 1893 in Brescia Scuola Italiana Moderna [Modern Italian School] (1893-present day) was born, a soon to be famous didactic magazine for elementary school teachers, read throughout Italy, which concentrated on practical teaching methods and suggestions (Cattaneo and Pazzaglia, 1997; Chiosso, 1997. pp. 622-627). In 1904 the Catholic national publishing house La Scuola (still in existence) was founded in Brescia to support this magazine. This publishing house then printed other school journals and many school textbooks (Pazzaglia, 2004).

\section{The Liberal AgE AT THE BEGINNING OF THE XX CENTURY} (1900-1921)

At the beginning of the XX century Italian universities had professors who were Positivist, neo-Kantian or Herbartian. Catholics, and neo-Idealists like Benedetto Croce and Giovanni Gentile were totally or partially excluded from university life until around the time of the First World War and its aftermath. The magazine La critica [The critic] edited by Croce (1903-44, in collaboration with Gentile until 1923) expressed vehement criticism of the aca- demic philosophical and pedagogical establishment, against Positivism and Herbartism. Around Croce and Gentile many bright intellectuals gathered: the new generation, which was dissatisfied with the exhausted materialism and Darwinism and the drytechnicism of Positivistic and Herbartian pedagogy (Turi, 2006).

The elementary school teachers, already grouped together in associations, joined the national union, founded in 1901 by Luigi Credaro (Unione magistrale nazionale, UMN) (Barausse, 2002). In the same year the union of secondary school teachers (Federazione nazionale insegnanti scuola media, FNISM) was set up by the socialists Gaetano Salvemini and Giuseppe Kirner (Ambrosoli, 1967). The Catholic wing quitted the UMN in 1908, since the Union had proved to be dominated by anti-Catholic feeling (the debate around the teaching of religion in schools was intense: Catholics wanted to re-establish it, while Socialists refused). The number of magazines of teachers' associations and of local sections increased until Fascism closed them in 1925. The number of didactic journals, conversely, kept decreasing, as was already happening at the end of the XIX century: small magazines were often absorbed by bigger ones, supported by powerful publishing houses (Chiosso, 1988b. pp. 11137-11140). These changes were an expression of the developments occurring within schools, with the rise in importance of teachers' unions and the industrialization of some northern parts of Italy. 
Meanwhile, a breakthrough occurred:the establishment of academic pedagogical journals, in which professors were fully engaged, hence providing new media: not only magazines about teaching and about teachers' rights, but journals that gave space to deep discussion of pedagogical theories. In 1906 in Pavia, Francesco Saverio De Dominicis, who held the chair of education there, published the Rivista di Pedagogia [Journal of Pedagogy] (1906-11), a last expression of the Positivism which had dominated the late XIX century (Chiosso, 1997, pp. 567-568). Two years later, Luigi Credaro set up the Rivista Pedagogica (1908-39) in Rome, as the mouthpiece of Herbartian and Kantian intellectuals, against Positivistic materialism and neo-Idealism, that reduced pedagogy to philosophy. Credaro surrounded himself with important educationalists like the neo-Kantian Giovanni Vidari from Turin; Giovanni Calò from Florence, who embraced a spiritualism not far removed from Herbartism; and Nicola Fornelli, a Herbartian and professor in Naples.

The Rivista Pedagogica published articles about the history of education, experimental education, the theory of education, also not forgetting school policy. Credaro was Minister of Education (1910-14) and in 1911 managed to win approval for the law that advocated elementary schools to the State, which had been already drawn up by his predecessor Edoardo Daneo. A leading exponent of Herbartism, Credaro supported teachers' cultural and economic battles, was involved in po- litics and carried out a significant cultural campaign through his magazine (Chiosso, 1997, pp. 570-572; D'Arcangeli, 2000, 2004; Chiaranda, 2005; D'Arcangeli and Messa 2009).

But in spite of his efforts, neoIdealism was gradually prevailing, thanks to the academic role of Gentile and later his actions as Minister of Education. Gentile, who held an academic teaching qualification both in Philosophy and in Pedagogy, entered the academic world in 1906 as professor of History of Philosophy in Palermo. In 1914 he was appointed Professor of Philosophy in Pisa. He was then called by Rome University in 1917. Gentile, like Croce, considered pedagogy to be a part of philosophy. In 1911 his friend Giuseppe Lombardo Radice, a fellow Sicilian by birth, was appointed professor of Pedagogy in Catania, moving to Rome in 1924 (to the Istituto di Magistero, antecedent of the present-day Faculty of Educational Sciences). In Florence Ernesto Codignola, a close associate of Gentile, had been teaching Pedagogy since 1918.

All these three intellectuals had studied Philosophy in Pisa, an institution which bore a strong Hegelian stamp. They were at the time friends. Whilst Gentile had stronger theoretical interests, Codignola and Lombardo Radice devoted their energies to the renewal of pedagogical thought and teaching and had close links to elementary school teachers. Lombardo Radice was a particularly clever educationalist, who gradually inserted Progressive education in- 
to the neo-Idealistic anthropology, always considering man as a spiritual being and thus stressing the artistic dimension of learning and the necessity to respect the psychology of children and their way of thinking. These men believed in the importance of teachers' culture, which must be improved through lifelong education. To this end, they developed a series of publications, publishing classic texts of philosophy and education - with Gentile dedicating himself more to secondary school (Ginnasio-Liceo) teachers - as well as new magazines.

In Palermo, Lombardo Radice set up I Nuovi Doveri [New Duties] (1907-11), and after the Great War L'Educazione Nazionale [National Education] (1919-33), which was an influential journal, featuring prestigious authors. In Florence, Codignola directed Levana (1922-28) and La nuova scuola italiana [The new Italian school] (1923-38). These journals (Chiosso, 1997, pp. 284-287, 395-397, 459-463) were the voice of the neoIdealist intellectuals and educationalists. (Cives, 1970; Fornaca, 1972; Chiosso, 1983; Cavallera, 1996; Tassinari and Ragazzini, 2003; Turi, 2006; Oliviero, 2007a; Cambi, 2010).

The debate about school policy also raged fiercely between the neoIdealistic journals and Credaro's Rivista Pedagogica. Credaro's neoHerbartism was accused of arid intellectualism. The neo-Idealists opposed positivistic materialism and the prevalence of didactics over the education of the human spirit. They advocatedschool reform, with an education to- wards a national conscience and patriotic ideals at its core. They acknowledged religious values and the necessity of a religious education for the popular and lower classes, thus gaining respect from the Catholic front. The complete history of these journals and these polemics has still to be undertaken - only Rivista Pedagogica has been studied by $D^{\prime}$ Arcangeli (2000): so far, historians have used other sources, mainly books or archival sources for Gentile. The so-called Giolitti's age was a vibrant cultural exchange of the utmost importance and these journals show the richness of the pedagogical debate over theories, methods and school policies, that involved professors as well as teachers, headmasters and inspectors, bearing witness to the cultural maturity of the Italian school world, at least the better part of it. Fifty years after unification, teachers' competence had improved and a pedagogical renewal was supported by the neo-Idealistic front.

The Great War had a strong impact on schools (Polenghi and Trebisacce, 2015). The title of Lombardo Radice's new magazine, L'Educazione $\mathrm{Na}$ zionale, testified to the shared need for a school system where patriotic and spiritual values were present.

\section{NeO-IDEAListic Reform AND FASCISM (1923-1945)}

Appointed Minister of Education in Mussolini's first government, Gentile managed to accomplish wide-ranging school reform in 1923, bringing years of debates and discussions to a point 
of culmination (Ostenc, 1980; Charnitzky, 1994, pp. 73-154). Lombardo Radice, his right-hand man as Director of Primary Schooling in the Ministry of Education, provided the new programs for elementary schools. Gentile and Lombardo Radice thoroughly upset the school editorial market, compelling the publishing houses to adhere to the reform and pedagogical neoIdealism (Sani, 2008; Chiosso, 2013; Polenghi, 2015). Codignola worked with them.

But after Matteotti's murder in 1924, in 1925 the dictatorship began. The reactions of the neo-Idealists were different and the united front broke down. Croce rejected Fascism and his relationship with Gentile assumed a tone of sore polemic. Lombardo Radice had already rejected Fascism in 1924 and resigned from his ministerial appointments. He was put under police surveillance. He remained a friend of Gentile, but developed a progressive pedagogy, gradually distancing himself from neo-Idealism. His journal L'Educazione Nazionale defended Gentile's School Reform from Fascist attacks and revisions. Apparently not political, his journal was nonetheless against the regime, and in 1933 it was closed down (Cives, 1983). In Levana, Codignola backed Gentile and his reform too, but also supported Mussolini until 1929-30, for he was critical of the Concordat with the Church and the dismantling of the liberal spirit of Gentile's reform.

The regime disbanded teachers' associations, but initially asked pedagogical and school magazines just to adhere to a national/nationalistic vision and to the Fascist schooling policy. In fact, many magazines could carry on, preserving the same editorial boards, among them I diritti della scuola [School Rights] (1899-2005) a very influential school magazine printed in Milan, the Catholic Scuola Italiana Moderna, and Credaro's Rivista pedagogica (up to 1939). The situation worsened in the Thirties. In 1930 the State single textbook was imposed in all elementary schools, thereby eradicating teachers' freedom (Sani, 2008); the compulsory oath for professors clearly became an oath of loyalty to Fascism.Non-fascist contributors had to leave editorial boards. New Fascist journals were founded, like Scuola fascista [Fascist School] directed by Luigi Volpicelli (1932-43) (Chiosso 1997, pp. 613-614).

Codignola abandoned Fascism from 1938 (his wife was Jewish). Lombardo Radice died in the same year. Another dissonant voice was Giovanni Calò, who from 1911 was professor of Pedagogy in the Faculty of Arts of Florence and director of the National Didactic Museum. Between 1929 and 1938, he edited its magazine La vita scolastica [School life], that dealt purely with teaching issues, but actually implied the refusal of a centralized school system. Calò was not a neoIdealist and gradually came close to a Christian humanism.(Scaglia, 2013).

In 1933 the Catholic magazine Scuola Italiana Moderna started publishing the Supplemento pedagogico [Pedagogical supplement] which was the very first scientific Catholic pe- 
dagogical journal (1933-42, 1948-52). Its leader was Mario Casotti, a philosopher who had followed Gentile and worked with Ernesto Codignola, developing pedagogical themes. He had been editor in chief of Levana and then of La Nuova scuola italiana. Like Codignola, he gradually abandoned neo-Idealism, until he firmly embraced the Catholic faith and neothomistic philosophy. Professor of pedagogy in Turin, in the Istituto di Magistero, he was appointed in 1924 by the Catholic University of Milan, founded in 1921 as a private university and recognized by Gentile in 1923. Around Casotti gathered a group of educationalists who carried on the tradition of the Catholic Italian pedagogy of the XIX century (Lambruschini, Capponi, Rosmini, Tommaseo, Don Bosco). Dévaud, Foerster and Ferrière published in the journal. Progressive education was known through Lombardo Radice's work and authors like Ferrière in particular (Chiosso, 2003b). No political references can be found in the Supplemento pedagogico of those years, as it is to be expected. In 1942 it ceased publication (Chiosso, 1997. p.627-628; Chiosso, 2001a. pp. 116-120, 182-185).

So whilst Gentile and Lombardo Radice managed to change Italian schooling in 1923, the dictatorship stopped the process of pedagogical renewal. No real debate was allowed and pedagogical magazines died out, or survived by not mentioning school policy or pretending to accept it, or by truly sharing fascist views on education. Montessori left Italy in 1934, the regime closed her schools and in 1936 also suppressed her Opera nazionale for teacher training.

\section{Republican ItAly AND DEMOCRACY (1946-1962)}

After the war, the role of schools and of civic education was perceived as central to the re-building of a national democratic identity. The key questions revolved around these issues: schooling and democracy; the role of classics in secondary schools (a central plank of Gentile's reform); the role of religion (reintroduced as a discipline by Gentile in 1923) in state schools; how to design a democratic middle school (for 11-14 year olds), since school was compulsory to the age of fourteen and Italy had three different middle school systems, based on pupils' social class, rather than on their merit and cognitive abilities (Sani, 2006; Palomba, 2008).

With the Republic, new school magazines for elementary and secondary school teachers, for lay and for Catholic teachers, for headmasters, for kindergarten educators and for school unions were set up. The old Scuola italiana moderna (Catholic) and I diritti della scuola (secular), which had managed to survive during the dictatorship, now flourished. Authoritative professors of pedagogy published in these two magazines, whose primary aim was to be a teaching tool for teachers. As for academic magazines, no scientific pedagogical journals had been issued since 1943: Credaro and Lombardo Radice's journals 
had been suppressed, the fascist magazines were suspended in 1943, and the others ceased publication due to the difficulties brought about by the conflict.

New scientific pedagogical journals were born in the aftermath of the war and in the Fifties. These new magazines were built upon the pedagogical philosophies of the earlier years and were directed by educationalists who had been active previously, but new ideas were also introduced which reflected the political and cultural situation of post-war Italy. A detailed and scientific analysis of these magazines has yet to be undertaken, so I shall limit myself to sketching the fundamental points.

With the arrival of democracy, new professors could be appointed and the situation of academic pedagogy reflected the political situation - once again, here we lack a detailed picture of the chairs of education in Republican Italy. We have to base our analysis on the biographies of some leading figures of professors of education and bear in mind some key questions. After the war Italy experienced a strong confrontation between the new Catholic Party (DC) and the Communist Party (PCI), which has to be seen as a reaction to the fall of the Fascist dictatorship but also has to be read in the international context of the Cold War.

The DC governed the country for years with the support of small parties which were heirs to a moderate liberal thought, until in 1963 the Socialist Party (PSI) joined the government, following preparations towards this in 1962, thus opening the new phase of the so called Centro-Sinistra (Centre-Left governments) (Ginsborg, 1989/90/2003).

In the cultural world, the Idealistic culture had persisted, for decades, in spite of the declared refusal of it. Many intellectuals had received a neo-Idealistic education, that still conditioned their approach. Ex-followers of Gentile like Casotti in Milan, Codignola in Florence, Volpicelli in Rome and Gino Ferretti in Palermo were all authoritative professors. Until the Seventies, the pedagogical debate often still bore a Gentilian stamp (Mencarelli, 1986, vol.1). Professors of pedagogy also taught history of education (which was mainly a history of pedagogical ideas, from an idealistic perspective) and didactics: the same professor had to master a number of different areas, and above all philosophy. Therefore, the new journals of pedagogy were magazines which dealt with pedagogical theories but also with the history of pedagogical ideas, and with didactics, experimental pedagogy and school policy: there was still a unitary conception of pedagogy as a whole, that was rooted in Idealism.

The scientific pedagogical journals reflected the academic (and political) cultural situation. We can in fact distinguish three main cultural trends: Catholic; Liberal, progressive and secular; and Communist. Their pedagogical projects reflected their ideas of democracy and their anthropologies. 


\section{IV.1. Catholic Journals}

The very first academic pedagogical journal was Rassegna di pedagogia [Review of Pedagogy] (1941-43, 1946present day), founded by Raffaele Resta and Giuseppe Flores D'Arcais in 1941, to fill the gap left by the closure of Credaro's Rivista pedagogica. In 1943 publication ceased, with Flores D'Arcais and Resta having refused to allow it to become the magazine of the Ministry of Education of the Republic of Salò, led by Mussolini but controlled by Nazi Germany.

Re-opened in 1946, Rassegna di pedagogia was edited for more than 50 years by Flores D'Arcais, of the University of Padua. Padua was one of the main centres of Catholic pedagogy and Flores D'Arcais was a clever exponent of Spiritualism and Personalism. The magazine hosted articles by important Italian authors, from Giovanni Calò of Florence to Luigi Stefanini of Padua, but also welcomed foreign articles, particularly from Germany (Flores D'Arcais had a Ph.D from Würzburg). It was critical towards Idealism, naturalism and pragmatism. From the Fifties, it also explored themes of school policy, such as teacher training and school reform (Zago, 2005, 2007, 2010).

If Rassegna di pedagogia represented the Paduan Catholic Institute of Pedagogy, Brescia, where the Catholic publishing house La Scuola was based, soon became a lively, thriving cultural centre, which released a new series of pedagogical publications and a new magazine. La Scuola was not only a schools publishing house, which edited textbooks and teachers' magazines, like the old Scuola italiana moderna: it became a type of national cultural workshop, that gave voice to Catholic professors from all over Italy. However, it had strong links with the Catholic University of Milan, which in 1965 opened a campus of the Faculty of teacher training (Facoltà di Magistero) in Brescia. From 1948 to 1952 the Supplemento pedagogico was published again. In 1953 it enjoyed a relaunch and reinvigoration, becoming Pedagogia e Vita [Pedagogy and life] (1953-present day). Mario Casotti was the managing editor of this journal from 1933 to 1971. The magazine represented pedagogical personalism and neo-Thomism. Gentile's reduction of pedagogy to philosophy was contested and Lombardo Radice's lessons were remembered. Pedagogia e Vita hosted articles on the history of education and didactics too, as well as articles by foreign authors: Eugène Dévaud, Friedrich Wilhelm Förster and Maria Boschetti Alberti. The theories of Makarenko, Decroly, Montesso$r i$ and Dewey were discussed. The school policy of foreign countries was also presented and debated.

This international perspective was present in Pedagogia e Vita as well as in Rassegna di Pedagogia (Chiosso, 2001a. pp. 167-187). In these journals the criticism of Marxism, atheism, secularism, naturalism and Idealism was strong. The progressive pedagogy was only gradually integrated. Casotti and Mauro Laeng, professor in Rome,expressed criticism of the lack of religious aims in Dewey, 
but appreciation for the methodology of his research and the influence of psychology (Laeng, 1955).

Unlike Gentile, Casotti accepted the support that psychology, sociology and biology could give to pedagogy, but he adhered to Gentile's views in firmly binding education to philosophy, not only to ethics but to metaphysics, in a thomistic perspective, whereas Stefanini referred to Plato and St. Augustine (Caimi, 1985). Maritain was a touchstone for the Catholic front, which was also rather suspicious of the technicality of didactics (here again one can see the influence of Gentile). Catholic educationalists refused the naturalism of progressive education, but accepted teaching innovations, thanks to the mediation of Eugéne Devaud, who had a good relationship with Decroly and who was well known in Italy. Even before the Second World War, Devaud was viewed in light of Lombardo Radice's method, thanks to some young Catholic teachers like Marco Agosti, who developed a "Christian progressive" education (Scaglia, 2015). In 1955 Pedagogia e Vita dedicated an issue (n.1) to progressive education: Casotti, Calò and Agosti saw the opportunity for a settlement between Catholic anthropology and active learning, which others like Catalfamo denied.

Montessori was associated with Positivism and had already been criticized by Giuseppe Lombardo Radice, who accused her method of being artificial and expensive. Montessori came back to Italy after the war, to revive her Opera Nazionale Montessori. So- me Catholics had indeed appreciated some parts of her methodology, but Montessori never belonged to the cademic world (in 1905, she had been only the fifth woman in Italy to gain the academic teaching qualification, but she never succeeded in integrating and eventually left the University, a male world where women were not really accepted) (Polenghi, 2008; Pironi, 2010).Gentile's influence can be perceived in this prolonged hostility towards empiric and experimental pedagogy, which was ultimately overcome, in the Catholic world, by the Salesians.

The Pontifical Salesian University opened in Turin in 1941 (it would later relocate to Rome in 1965). In 1956 the Istituto superiore di pedagogia (not yet a Faculty, but a strong educational centre) was opened, two years after the launch of a pedagogical magazine, named Orientamenti pedagogici [Pedagogical Guidelines] (1954 - present day). Young Salesians had been sent to the USA, Louvain and Freiburg to refine their education. The journal, edited by Don Pietro Braido, published many historical essays, especially on Don Bosco, as well as on the history of religious education (by Braido himself); articles on experimental pedagogy and didactics: Don Luigi Calonghi had studied at Leuvain with Raymond Buyse; Renzo Titone had studied in the USA, UK, France and Germany; Gino Corallo went to the USA and published a detailed and critical book on Dewey (Corallo, 1950). Braido, like Casotti, defined pedagogy as a speculative and practical science, thus giving 
voice to experimental education on the basis of Aristotle.

\section{IV.2. Secular and Progressive pedagogy}

The real introduction of Dewey in Italy is due to the liberal and secular front, led by Codignola and Borghi. Codignola dropped Idealism in favour of pragmatism. He had met Carleton Washburne, who came to Italy in 1943 with the American army and stayed until 1948. Lamberto Borghi, being Jewish, had left Italy after the racial law of 1938 and went to the USA, where he met John Dewey and William H. Kilpatrick. He then became a full professor of pedagogy in Palermo in 1952 and in 1955 replaced Codignola in Florence, where he remained until 1982. Borghi spread Dewey's thought, until then little known in Italy, editing many books of his and adopting and discussing his pedagogical theory. Democracy had to be created on the basis of a rational religious faith, not a denominational one. State schools had to be neutral in terms of religion (Tassinari, 1987). In 1950 Codignola set up the magazine Scuola e città [School and city](1950-2003), which was a mouthpiece for this trend of neo-enlightenment, liberal and progressive pedagogy.

Following Codignola's death, Borghi became the managing editor of Scuola e città, from 1965 to 1972. Aldo Visalberghi, like Borghi, a Philosophy graduate from Pisa, (with a thesis on Benedetto Croce), won a Fulbright scholarship and was in the USA in
1952-53, where he met Washburne and Kilpatrick. Later Professor of Pedagogy in Turin, Milan and Rome between 1962 and 1989, Visalberghi, who was a Socialist, edited Dewey's translations and disseminated a liberal pedagogy, which was both tolerant and pacifist. He was also editor of Scuola e città. He wrote about evaluation and empirical research. Scuola e città spread Dewey and a neo-enlightened humanism. It boasted an international editorial board, with R.Cousinet, A. Ferrière, C.Washburne, P.Volkov, L.Meylan, and J.Lauwerys, and published articles by Freinet and J. Kilpatrick. The journal voiced strong criticism of the school policy of the Catholic Party Democrazia Cristiana and therefore of the Ministry of Education, which was held by the DC for thirty years. The questions of religion as a school subject and of religious private schools produced heated debate.

In 1955 the Minister Ermini issued a new curriculum for elementary schools, largely based on progressive pedagogy and personalism, where Catholic religion had a key role. Scuola e città disputed this (for instance the compulsory morning prayer in classrooms was contested). In the Sixties the journal leaned towards socialism, due to the influence of Tristano Codignola, Ernesto's son, who as an MP, and later senator, held responsibility for the school policy of the Socialist party (PSI). In the Seventies Scuola e città abandoned Dewey in favour of Marxism (Cambi and Striano, 2010).

Another relevant journal was I problemi della scuola [School problems] 
(1955-present day), edited by Luigi Volpicelli until 1983, when his son Ignazio took over. A follower of Gentile, Volpicelli had helped Giovanni Bottai in writing his Carta della Scuola [School Charter], the fascist school law issued in 1939. In the same year, on the death of Lombardo Radice, Volpicelli succeeded him to the chair of Pedagogy in Rome. Volpicelli rejected Progressive education and psychological functionalism and favoured Spranger, Litt, and above all Hessen: the philosophy of values was opposed to Dewey's ethical pragmatism (Chiosso, 2015, pp. 100-102; Zizioli, 2009). Again, Gentile's stamp was still in evidence. Around Luigi Volpicelli's journal various professors of pedagogy gathered, with different views, but certainly all in favour of secularism.

\section{IV.3. Communist pedagogy}

In the aftermath of the war the Communist Party (PCI) did not develop a school policy but concentrated on political organization and militancy, modelled on the Soviet example. Catholic education was rejected as dogmatic; denominational schools were considered dangerous; Dewey's pedagogy was accused of being a false doctrine of freedom, an expression of American capitalism (Ragazzini, 1987, pp. 106-187; Semeraro, 1982; Tassinari, 1987; Pruneri, 1999).

In 1955 the Communist Party started to publish Riforma della Scuola [School Reform] (1955- present day). The managing editor was Lucio Lombardo Radice, Giuseppe's son, a mem- ber of the PCI, and a professor of mathematics with a deep interest in education, clearly inspired by his father. The Editor in chief was Dina Bertoni Jovine, an elementary school teacher, member of the PCI, and author of relevant books on the history of education and schooling, who had only managed to enter the academic world in 1967, when she became professor of Pedagogy in Catania (Semeraro, 1979). The magazine was the official voice of the educational and school policy of the PCI. The editorial board boasted intellectuals such as Antonio Banfi, professor of philosophy and Concetto Marchesi, professor of Latin literature, protagonist of many cultural debates, and member of the Constituent Assembly of the Italian Republic (1946-48).

Riforma della Scuola accepted Antonio Gramsci's interpretation (his books had been published since 1948 and had gradually influenced Italian Communism). Gramsci's reappraisal of culture and ideology, whereby they were not seen as mere superstructure, but as a powerful tool for class hegemony, allowed him to assign greater importance to school and education. The project of school reform was political as well as pedagogical.The first revolution had to happen in men's consciences (Broccoli, 1972). Bertoni Jovine published many articles on the history of schooling and education, giving space to popular education and reading schooling as an aspect of the class struggle. Contrary to Dewey, she linked discipline to responsibility: naturalness did not grant freedom. However, she praised Giuseppe Lombar- 
do Radice, who had been her professor in Rome and whose ethics lessons she never forgot. School, as Gramsci stated too, was a key element in the revolution of consciences. Nonetheless, the support for Anton S. Makarenko and the criticism towards progressive education started to be contested within the PCI, when some teachers began to use less directive teaching methods, thus allowing Dewey's and Freinet's didactics to enter into their practice. The communist teacher Bruno Ciari, previously a student of Codignola in Florence, joined the editorial board of the magazine, after having published in 1961 Le nuove tecniche didattiche, hence opening the journal to progressive pedagogy.

It is interesting to check which foreign authors were discussed in the academic journals from the Fifities up to 1992 . We shall limit the analysis to the titles of articles of Scuola e città, Pedagogia e vita and Riforma della scuola (results elaborated from the data collated by Scarpellino, 2104). (Table n.1)

Clearly these results are partial, for they should also take into account other journals and items, such as translations and books on these authors. Nonetheless, we can offer some observations. Dewey is by far the most commonly discussed author, with 49 articles, but 38 (28 in the first two decades) appeared in Scuola e città, which was really the driving force behind his public platform. The second author is Gramsci, with 29 quotations, 23 of them in Riforma della scuola (16 after 1970). Piaget scores 20 arti- cles, particularly in Scuola e città after 1970 (10). Lombardo Radice is referenced in 19 articles, and is discussed by all three journals, but particularly by Pedagogia e vita (10), during the 40 years. Gentile scores 16, but it is Pedagogia e vita that dedicates 14 articles to him, 8 of them before 1970, mainly by his ex-follower Casotti, who continued to discuss neo-Idealism.

Marx gets the same score, with 10 articles in Riforma della scuola, as was to be expected, but 7 of them before 1970 -after which Gramsci led the score. 14 articles were dedicated to Montessori, with a slight predominance in Pedagogia e vita (6). Maritain was discussed 13 times, but only by Pedagogia e vita. The same can be noted for Förster, who was quoted 12 times by Pedagogia e vita, but only up until 1970. Freinet was quoted by the three journals, although mainly by Scuola e città (8). Authors like Makarenko, Illich, Bruner and Vygotskij appear in all three journals, whereas others appear only in one (Dèvaud, Hessen, Kerschensteiner, Spranger, Willmann in Pedagogia e vita) or in two. Progressive education seems to be concentrated on the key figure of Dewey, widely discussed in Codignola's Scuola e città, while Catholic educationalists concentrated on Förster and Maritain, but still debated neo-Idealism and Giuseppe Lombardo Radice. Communist discussion revolved around the work of Marx and Gramsci.

Each journal makes reference to its own standard-bearers: Dewey, Maritain, and Gramsci, and there is a 
Table 1: Most quoted contemporary educationalists in the titles of articles of 3 Journals 1950-92

\begin{tabular}{|c|c|c|c|c|c|c|c|c|c|c|}
\hline \multirow[t]{2}{*}{ Educationalists quoted in the title of articles } & \multicolumn{3}{|c|}{ Scuola e città } & \multicolumn{3}{|c|}{ Pedagogia e vita } & \multicolumn{3}{|c|}{ Riforma della scuola } & \multirow{2}{*}{$\begin{array}{l}\text { All three } \\
\text { Total }\end{array}$} \\
\hline & $1950-70$ & 1971-92 & Total & $1950-70$ & 1971-92 & Total & $1950-70$ & $1971-92$ & Total & \\
\hline Bruner & & 3 & 3 & 1 & 2 & 3 & & 3 & 3 & 9 \\
\hline Claparède & 2 & & 2 & 1 & & 1 & & & & 3 \\
\hline Cousinet & 1 & 1 & 2 & 3 & 1 & 4 & & & & 6 \\
\hline Croce & 2 & & 2 & 3 & 3 & 6 & & & & 8 \\
\hline Decroly & 1 & & 1 & 5 & & 5 & & & & 6 \\
\hline Dèvaud & & & & 3 & & 3 & & & & 3 \\
\hline Dewey & 28 & 10 & 38 & 4 & 4 & 8 & 1 & 2 & 3 & 49 \\
\hline Förster & & & & 12 & & 12 & & & & 12 \\
\hline Freinet & 5 & 3 & 8 & 1 & & 1 & 1 & 2 & 3 & 12 \\
\hline Gentile & 1 & 1 & 2 & 8 & 6 & 14 & & & & 16 \\
\hline Gramsci & & 3 & 3 & 1 & & 1 & 7 & 16 & 23 & 29 \\
\hline Hessen & & & & 2 & & 2 & & & & 2 \\
\hline Kerschensteiner & & & & 3 & & 3 & & & & 3 \\
\hline Kilpatrick & 1 & 1 & 2 & 1 & & 1 & & & & 1 \\
\hline Illich & & 1 & 1 & & 2 & 2 & & 3 & 3 & 3 \\
\hline G.Lombardo Radice & 1 & 4 & 5 & 5 & 5 & 10 & 3 & 1 & 4 & 19 \\
\hline Makarenko & 1 & 1 & 2 & 3 & & 3 & 5 & & 5 & 10 \\
\hline Maritain & & & & 3 & 10 & 13 & & & & 13 \\
\hline Marx & & 1 & 1 & 1 & 4 & 5 & 7 & 3 & 10 & 16 \\
\hline Montessori & & 5 & 5 & 5 & 1 & 6 & 3 & & 3 & 14 \\
\hline Piaget & 1 & 10 & 11 & 1 & 2 & 3 & 4 & 2 & 6 & 20 \\
\hline Skinner & & & & 2 & & 2 & & 1 & 1 & 3 \\
\hline Spranger & & & & 2 & & 2 & & & & 2 \\
\hline Suchodolski & & 1 & 1 & & & & 2 & 2 & 4 & 5 \\
\hline Vygotskij & & 2 & 2 & 1 & & 1 & & 4 & 4 & 7 \\
\hline Washburne & 1 & 1 & 2 & 1 & & 1 & & & & 3 \\
\hline Willmann & & & & 2 & & 2 & & & & 2 \\
\hline
\end{tabular}

clear separation of interests (some authors are relevant only to one magazine, that is to say the other/others do not even discuss them). A crossplatform interest is to be detected for Lombardo Radice and Dewey, and to

\section{From the Single middle SCHOOL (1962) TO THE CRISIS OF IDEOLOGIES}

During the Fifties there was a stark opposition of ideologies. The language used was also militant and reflected the Cold War atmosphere. In its very first editorial, Pedagogia e vita decla- a lesser degree for Montessori, Freinet and later for Piaget and Bruner, as well as Illich, who is discussed in each of the three journals. Lombardo Radice (more than Gentile) appears to be an author of ongoing influence.

red that one of its aims was to "prepare the educators to defend our glorious traditions in the school trenches, where battles for the success of values are really won or lost" (Pedagogia e vita, 1952, n.1, p. III). Scuola e città in an article of 1950 wrote that the separation between Catholic and secular education had to be total: "Our op- 
position to the magisterium that the Church intends to exert through State institution is a radical opposition, calm but irreconcilable" (Rodelli, 1950, p.118). France was quoted as a model of the secular State, often opposed to Franco's Spain.

The expectations raised by the substantial participation of teachers $(211,000)$ in the national survey (1947-49), promoted by the Catholic minister of education Guido Gonella, died with the failure of his attempt at school reform in 1950-51. Accused of defending Catholic schools, Gonella faced a firestorm of objections. The sharp ideologization of the debates rendered a parliamentary school law impossible, leading to a reversion to a school policy carried out through administrative acts (Gaudio, 1991, Semeraro, 1991; Chiosso, 2001b, 2001c).

As a consequence of this stagnation, Italian schools were basically still governed by Gentile's reform.But in an age of rapid industrialization and social change and in a democratic country where illiteracy was strongly fought, the existence of three different types of middle school, based on parents' social class more than on $\mathrm{pu}-$ pils' abilities, was the heritage of an outdated world. The sticking point in the debate (in fact since 1905) was the role of Latin, whether it should be kept, which favoured the preparation of future pupils of GinnasioLiceo classico (secondary grammar schools -with a classics-based curriculum), or dropped, as unnecessary for children of the lower classes. The debate was long and also invol- ved teachers' associations, which were engaged in establishing new jobs: a post-elementary school could appoint elementary school teachers, whereas a middle school with a more complex and wider curriculum needed teachers with a degree, as indeed was the final decision. The law 31 dec.1962 n.1859 gave rise to the single middle school (11-13 yrs) (Scuola media unica , which still had Latin, but as an optional subject, which was eventually dropped in 1977. The political shift in the government, with the new alliance between the Catholic (DC) and the Socialist (PSI) parties allowed this goal to be reached (Pazzaglia, 2001b).

Tristano Codignola, in the PSI, was a leading figure in this reform. The academic pedagogical world was quite united in supporting the reform. In fact, leaving aside minor differences, and once the position of the Catholic elementary school teachers, who supported a post-elementary school, was resolved, for pedagogical reasons within the Catholic faction, the backing was fairly uniform. Riforma della Scuola published many articles in favour of the single middle school, with better qualified teachers. The communist professor of Latin, Marchesi was in favour of compulsory Latin, because of its educational value, but the Communist Party and magazine stressed the importance of sciences and of Italian scientific traditions.

In its first editorial Riforma della Scuola had already observed that the values of the classical world had to be kept only in the Liceo classico, as the ideal of Humanity for the new ge- 
neration "cannot be now the classic Greek-Roman world, but it must be the mighty age in which modern civilization had its dramatic and enlightened beginning, that is to say the Renaissance, which finds in whole men like Leonardo and Galileo its highest symbol". Latin had to be eliminated from every kind of school, except the Liceo classico (Riforma della Scuola, 1955, n.1).

Marchesi's position, in favour of the educational value of Latin as a logical language, was a minority one on the political left (Pazzaglia, 2001a).The battle for Latin was also hindered by the memory of the nationalistic defence of Latin during the Fascist regime, even if Giovanni Bottai actually also stressed the natural link between Latin and Italian, enhancing the linguistic heritage in his school reform of 1939 (Gentili 1979). The 1962 single middle school law was a democratic result (after decades of debate) that came also from the engagement of professors of different cultural perspectives, since it was supported by the academic world, both secular and Catholic, for its democratic impact. From a pedagogical point of view, Hessen's theory was also relevant. As a result, the single middle school had different disciplines, which had to be taught by specialist subject teachers, who had to have a degree and a teaching qualification (Oliviero, 2007b).

In 1968 another relevant law was passed, concerning State kindergartens: pre-school age children (3-5 years) should have the opportunity to attend a State kindergarten. Up until then, infants' schools had been largely set up by Church institutions (Bobbio, 2016).

In the Fifties and Sixties, the teaching profession, both secular and Catholic, was heavily involved in social battles, for adult education and literacy, for family education, for the inclusion of disabled people (from the Sixties onwards), for school renewal and changes in teaching methods (Fornaca, 1982). Pedagogy as an academic discipline was linked with philosophical and didactic questions (teacher training) as well as social and political issues. Southern Italy's educational problems were debated in Prospettive pedagogiche [Pedagogical perspectives] (Messina 1964-present day), edited by the Catholic Giuseppe Catalfamo. The personal political involvement of various professors was the expression of a civic feeling after Fascism. The cultural debate revolved around pedagogical theory and anthropology, and school policy. Progressive education, supported by Scuola e città, was gradually accepted and incorporated into the Christian tradition, by Rassegna di pedagogia and Pedagogia e vita, and into the communist perspective by the young generation of teachers.

The 1968 movement, the boom of enrolments in universities, leading to the creation of a mass society university population, the fall of the Berlin wall in 1989 and the breakdown of communist ideology, together with the shattering of the Italian Catholic and Socialist parties, secularism, modernisation, social and cultural chan- 
ges that have affected Italy as well, all of these have affected pedagogical theories. In the Nineties primary school teacher training was raised to university level (Fornaca, 1982; Mencarelli, 1986, vol.2; Chiosso, 2015, pp. 115-230). In 1995 the Teacher Training Faculty (Facoltà di magistero) became the Faculty of Educational Sciences (Facoltà di Scienze della formazione), a change that clearly opened up graduate career pathways into the fields of socialcare and welfare. Academic pedagogy is oriented towards extra school jobs too. The collapse of ideologies, the creation of new chairs in the Nineties and the pressure towards specialisation led to particular consequences. The number of professors increased, but a mapping of the pedagogical chairs is still lacking ${ }^{1}$.

At the same time, the idea of general pedagogy as the encyclopaedia of all pedagogical knowledge has faded (Mariani, 2008). The breakdown of ideological barriers has generally produced respect for different anthropologies, but the risk of relativism is very strong (Acone, 1994, 2004). Teaching methods, new media and ICT have gained ground, so that technological tools, important as they are, may overwhelm the anthropological foundation of education in teacher education and school policy. School policy is largely dominated by sociologists, economists and scientists, rather than by professors of education. Obsessed for decades by Gentile's heritage, eventually dismissed as a curse, Ita- lian pedagogy lost its tradition and its links with a sound anthropological perspective, thereby losing the capacity to read and interpret the present, shackling itself to empirical analysis and limiting itself to teaching methods. In the traditional scheme of ends and means, the latter now prevail (Massa, 1987; Chiosso, 2015, pp. 255-257).

\section{CONClusions}

In the XIX century there were no academic journals, since the discipline was limited to few chairs and was always linked to philosophy. Many school magazines for teachers were founded. The need to improve the cultural background of elementary school teachers stimulated the birth of these useful magazines. At the dawn of the XX century a strong confrontation took place between Positivism and Herbartism, and a growing neo-Idealistic front. Academic journals were one of the places where this struggle was played out. During the Fascist regime, neo-Idealism, Fascism, and Catholic educational theories took centre stage. With the Republic, Catholic, secular-progressive and communist ideologies became dominant in the political as well as in the academic world. Professors of pedagogy became engaged in societal problems and politics; new academic journals reflected this ethical and political engagement, as well as the scientific debate, which revolved around to-

\footnotetext{
${ }^{1}$ Roberto Sani is leading the Italian group in the Standing Work Group of ISCHE Mapping the discipline 1987-2014, which will reconstruct the last 30 years ofchairs.
} 
pics like progressive education, school reform and democracy. The mass expansion in the school and university populations, the increase of educational chairs, the growing importance of teaching methods and of specialization, the collapse of Communism, the spread of secularism and relativism and the new ministerial evaluation criteria have all produced significant effects: a fragmentation of pedagogy, split into micro sectors; the dramatic growth of academic journals; the fading of ideological barriers.

The pressure for internationalization and new ministerial models of scientific evaluation, together with the aforementioned changes, have produced in the last decade an explosion in the number of scientific journals. We have many journals, probably too many. In 201441 journals were classified as first rate (A), plus other new ones are striving to attain this ministerial evaluation (Baldacci, 2014, p.15). Very few however are in Scopus or WoS. Every pedagogical discipline has its own society and therefore journal (media education, special education, empiric education, family education, children's education, adult education, etc). A comparative (also international) analysis of these magazines still has to be done (Knaupp et al, 2014).

In history, however, a clear step forward has been made. Whereas before, historic articles were published in general education magazines, now, with the separation of history of education from the chair of pedagogy in the Eighties and the shift from a neo-Idealistic history of ideas to a history of schooling and education; with new sources and methods, and archival competences, specific journals have been born: Studi di storia dell'educazione [Studies of history of education] (1980-95) by Fabrizio $R a$ vaglioli; in 1981 the review of the Italian Society for History of Education started a publication, originally as a thin bulletin, which was then totally restructured and now renamedRivista di storia dell'educazione [Journal of history of education] (Florence, 1981-present day); in 1994 Luciano Pazzaglia, with other professors of the Catholic University of Milan and Dominique Julia, set up Annali di storia dell'educazione e delle istituzioni scolastiche [Annals of history of education and school institutions] (1994-present day) through the Catholic publishing house La Scuola, which hosted articles by foreign historians; in 2006 Roberto Sani, previously professor in the Catholic University of Milan, then rector of the University of Macerata, founded and directed History of Education \& Children's Literature (2006-present day), a journal with an impressive international board, which soon registered on Scopus and WoS.

It is not the case that the titles of these magazines always refer to the history of education as opposed to the history of pedagogy, thus underlining their distance from an idealistic approach; the last magazine has an English title, for it aimed to become an international journal from the very beginning. 


\section{BIBLIOGRAPHY}

Acone, Giuseppe (1994): Declino dell'educazione e tramonto d'epoca. Brescia, La Scuola.

Acone, Giuseppe (2004): La paideia introvabile : lo sguardo pedagogico sulla post-modernità. La Scuola, Brescia.

Ambrosoli, Luigi (1967): La Federazione Nazionale Insegnanti Scuola Media dalle origini al 1925. La nuova Italia, Firenze.

Baldacci, Massimo (2014): La valutazione delle riviste pedagogiche. Un itinerario critico. Pedagogia oggi, 6. 2. 13-19.

online: http://www.siped.it/wpcontent/uploads/2014/11/pedagogia _oggi_2-2014.11-19.pdf last access: 10.5.2016

Barausse, Alberto (2002): L' Unione magistrale nazionale: dalle origini al fascismo, 1901-1925. Brescia, La Scuola.

Bobbio, Andrea (2016): From mother to woman. The child's socialization in the Italian kindergarten from the 60 s to the 90s. Assistance, citizenship and education. History of Education $\mathcal{E}$ Children's Literature. IX. 2. forthcoming.

Brezinka, Wolfgang (2000-2014): Pädagogik in Österreich: die Geschichte des Faches an den Universitäten vom 18. bis zum 21. Jahrhunderts. Voll.4. Verlag der Österr. Akad. der Wiss, Wien.

Broccoli, Angelo (1972): Antonio Gramsci e l'educazione come egemonia. La nuova Italia, Firenze.

Caimi, Luciano (1985): Educazione e persona in Luigi Stefanini. La Scuola, Brescia.
Cambi, Franco (2010): Cultura e pedagogia nell'Italia liberale (1861-1920): dal positivismo al nazionalismo. Unicopli, Milano.

Cambi, Franco and Striano, Maura (2010, eds.): John Dewey in Italia: la ricezione/ripresa pedagogica: letture pedagogiche. Liguori, Napoli.

Cattaneo, Mario and Pazzaglia, Luciano (1997): Maestri, educazione popolare e società in Scuola italiana moderna, 1893-1993. La Scuola, Brescia.

Cavallera, Hervé A. (1996): Riflessione e azione formativa: l'attualismo di Giovanni Gentile. Fondazione Ugo Spirito, Roma.

Charnitzky, Jürgen (1994): Die Schulpolitik des faschistischen Regimes in Italien (1922-1943). Max Niemeyer Verlag, Tübingen.

Chiaranda, Mirella (2005): Finalità civili e politiche delle "Rivista pedagogica" di Luigi Credaro. In: Chiaranda Mirella (ed.): Teorie educative e processi di formazione nell'età giolittiana. Pensa Multimedia, Lecce. 89-128.

Chiosso, Giorgio (1983): L' educazione nazionale da Giolitti al primo dopoguerra. La Scuola, Brescia.

Chiosso, Giorgio (1988a): I cattolici e la scuola dalla Costituente al Centro-sinistra. La Scuola, Brescia.

Chiosso, Giorgio (1988b): Stampa pedagogica e scolastica periodica. In Laeng Mauro (dir.): Enciclopedia pedagogica. La Scuola, Brescia, vol. 6.,col.11123-11153.

Chiosso, Giorgio (1989, ed.): Scuola e stampa nel Risorgimento: giornali e riviste per l'educazione prima dell'unità. F. Angeli, Milano. 
Chiosso, Giorgio (1992): I periodici scolastici nell'Italia del secondo Ottocento. La Scuola, Brescia.

Chiosso, Giorgio (1993, ed.): Scuola e stampa nell'Italia liberale: giornali e riviste per l'educazione dall'unita a fine secolo. La Scuola, Brescia.

Chiosso, Giorgio (1997, ed): La stampa pedagogica e scolastica in Italia, 1820-1943. La Scuola, Brescia.

Chiosso, Giorgio (2001a): Profilo storico della pedagogia cristiana in Italia, 19. e 20. Secolo. La Scuola, Brescia.

Chiosso, Giorgio (2001b): Motivi pedagogici e politici nei lavori dell'inchiesta Gonella (1947-1949). In: Pazzaglia, Luciano and Sani Roberto (eds.): Scuola e società nell'Italia unita. Dalla Legge Casati al Centro-Sinistra. Brescia, La Scuola. 375-396.

Chiosso, Giorgio (2001c): Cattolici e riforma scolastica. L'Italia nel secondo dopoguerra (1949-1951). In: Pazzaglia, Luciano and Sani Roberto (eds.): Scuola e società nell'Italia unita. Dalla Legge Casati al Centro-Sinistra. Brescia, La Scuola. 397-420.

Chiosso, Giorgio (2003a, dir.): TESEO: tipografi e editori scolasticoeducativi dell'Ottocento. Bibliografica, Milano.

Chiosso, Giorgio (2003b): La pedagogia cattolica e il movimento dell'educazione nuova. In: Pazzaglia Luciano (ed.): Chiesa, cultura e educazione in Italia tra le due guerre. La Scuola, Brescia. 287-328.

Chiosso, Giorgio(2008, dir.): TESEO'900 : editori scolastico-educativi del primo Novecento. Bibliografica, Milano.
Chiosso, Giorgio (2013): Libri di scuola e mercato editoriale. Dal primo Ottocento alla Riforma Gentile. Franco Angeli,Milano.

Chiosso, Giorgio (2015): La pedagogia contemporanea. La Scuola, Brescia.

Chiosso, Giorgio and Sani, Roberto (2013, dir.): DBE : Dizionario biografico dell'educazione, 1800-2000. (2 vol.). Bibliografica, Milano.

Ciari, Bruno(1961): Le nuove tecniche didattiche. Editori Riuniti, Roma.

Cives, Giacomo (1970): Giuseppe Lombardo Radice : didattica e pedagogia della collaborazione. La Nuova Italia, Firenze.

Cives, Giacomo (1983): Attivismo e antifascismo in Giuseppe Lombardo Radice : critica didattica o didattica critica? La Nuova Italia, Firenze.

Corallo, Gino (1950): La pedagogia di Giovanni Dewey. SEI, Torino.

D'Arcangeli, Marco Antonio (2000): Luigi Credaro e la Rivista pedagogica (1908-1939). Tipolitografia Pioda, Roma.

D'Arcangeli, Marco Antonio (2004): L' impegno necessario : filosofia, politica, educazione in Luigi Credaro, 1860-1914.Anicia, Roma.

D'Arcangeli, Marco Antonio and Messa, Fausta (2009): Luigi Credaro e la Rivista pedagogica: atti del Convegno, Sondrio, 21-22 settembre 2007. Istituto sondriese per la storia della resistenza e dell'età contemporanea.

Fornaca, Remo (1972): Pedagogia italiana del Novecento : dall'inizio del secolo al primo dopoguerra. A. Armando, Roma. 
Fornaca, Remo (1982): La pedagogia italiana contemporanea. Sansoni, Firenze.

Gaudio, Angelo (1991): La politica scolastica dei cattolici : dai programmi all'azione di governo, 1943-1953. La Scuola, Brescia.

Gentili, Rino (1979): Giuseppe Bottai e la riforma fascista della scuola. Firenze, La nuova Italia.

Ginsborg, Paul (1989/1990/2003): A history of contemporary Italy: society and politics, 1943-1988. Einaudi/Penguin/Palgrave Macmillan, Torino/London/New York.

Knaupp, Monika, Schaufler, Sarah, Hofbauer, Susann and Keiner, Edwin (2014): Education Research and Educational Psychology in German, Italy and the United Kingdom -an Analysis of Scholarly Jounrals. Schweiseriche Zeitschrtift für Bildungswissenschaften, 36. 1. 83-106.

Laeng, Mauro (1955): Valori e disvalori nel pensiero di J.Dewey. Pedagogia e vita, XIV. 2 140-141.

Massa, Riccardo (1987): Educare o istruire? La fine della pedagogia nella cultura contemporanea. Unicopli, Milano.

Mariani Alessandro (2008): La decostruzione in pedagogia : una frontiera teorico-educativa della postmodernità. Armando, Roma.

Mencarelli, Mario (1986): Il discorso pedagogico in Italia, 1945-1985. Vol. 2. Tibergraph, Città di Castello.

Oliviero, Stefano (2007a): L'editoria scolastica nel progetto egemonico dei neoidealisti. ETS, Pisa.

Oliviero, Stefano (2007b): La Scuola media unica : un accidentato iter le- gislativo. Centro Editoriale Toscano, Firenze.

Ostenc, Michel (1980): L'éducation en Italie pendant le fascisme. Publications de la Sorbonne, Paris.

Palomba, Donatella (2008): Education and State Formation in Italy. In: Cowen, Robert and Kazamias, Andreas M. (eds): International Handbook of Comparative Education. Springer, Berlin. 195-216.

Pazzaglia, Luciano (2001a): Il dibattito sulla scuola nei lavori del1'Assemblea Costituente. In: Pazzaglia, Luciano and Sani, Roberto (eds.): Scuola e società nell'Italia unita. Dalla Legge Casati al Centro-Sinistra. La Scuola, Brescia. 327-356.

Pazzaglia, Luciano (2001b): La politica scolastica del Centro-sinistra. In: Pazzaglia Luciano and Sani Roberto (eds.): Scuola e società nell'Italia unita. Dalla Legge Casati al Centro-Sinistra. La Scuola, Brescia. 481-495.

Pazzaglia, Luciano (2004): Catalogo storico: editrice La Scuola, 1904-2004. La Scuola, Brescia.

Pironi, Tiziana (2010): Femminismo ed educazione in età giolittiana: conflitti e sfide della modernità. ETS, Pisa.

Polenghi, Simonetta (2008): «Non spostare artificialmente dalla missione naturale». Le donne e l'università tra Otto e Novecento. In: Ghizzoni Carla and Polenghi Simonetta (eds.): L'altra metà della scuola. Educazione e lavoro delle donne tra Otto e Novecento. SEI, Torino. 285-318.

Polenghi, Simonetta (2015): Giovanni Gentiles Schulreform zwischen Liberalismus und Totalitarismus. Von der Revision der Schulbucher (1923) 
zum „Staatsbuch" (1930). Historia Scholastica, 1. 1. 56-68.

Polenghi, Simonetta and Trebisacce, Giuseppe 2015, eds.): La gioventù europea e la Grande guerra: scuola, pubblicistica ed associazioni. Monographical issue of Rivista di storia dell'educazione, 2. 1 .

Ragazzini, Dario (1987): Dall'educazione democratica alla riforma della scuola. Napoli Liguori.

Rodelli, Luigi (1950), Il nostro laicismo. Scuola e città, 3. 117-119.

Romano, Mario (1925): Il giornalismo pedagogico nel Risorgimento e in Torino. Rivista pedagogica, 9. 761-766.

Sani, Roberto (2006): Schools in Italy and Democracy Education in the Aftermath of the Second Word War. History of Education \& Children's Literature, I. 2. 37-54.

Sani, Roberto (2008): The «Fascist reclamation» of textbooks from the Gentile Reform to the School Charter of Bottai. History of Education $\mathcal{E}$ Children's Literature, III. 2. 305-335.

Scaglia, Evelina (2013): Giovanni Calò nella pedagogia italiana del Novecento. La Scuola, Brescia.

Scaglia Evelina (2015): The Regents' System of Marco Agosti between Fascism and democracy. History of Education E Children's Literature, X. 1. 369-391.

Scarpellino, Vincenco (2014): Battaglie politiche e passioni pedagogiche. $\mathrm{Ri}$ viste a confronto (1950-1962). Università degli studi Suor Orsola Benincasa, Napoli.

Semeraro, Angelo (1979): Dina Bertoni Jovine e la storiografia pedagogica nel dopoguerra. Lacaita, Manduria.

Semeraro, Angelo (1982): Il Pci e la scuola dal dopoguera al sessantotto. Critica marxista, 1.145-166.

Semeraro, Angelo (1991): Elogio dell'educazione laica: Momenti di un dibattito (1945-1955). Studi Storici, XXXIII. 3. 701-727.

online: http://www.jstor.org/ stable/20565468

Tassinari, Gastone (1987, ed.): La pedagogia italiana nel secondo dopoguerra. Atti del Convegno in onore di Lamberto Borghi. Le Monnier, Firenze.

Tassinari, Gastone and Ragazzini, Dario (2003, eds.): Ernesto Codignola pedagogista e promotore di cultura. Carocci, Roma.

Turi, Gabriele (2006): Giovanni Gentile: una biografia. UTET, Torino.

Zago, Giuseppe (2005): Il dibattito sulla formazione degli insegnanti nella "Rivista Pedagogica". In: Chiaranda, Mirella (ed.): Teorie educative e processi di formazione nell'età giolittiana. Pensa Multimedia, Lecce.

Zago, Giuseppe (2007): Incontri e scontri del personalismo patavino. Il dibattito sull'attivismo nei primi anni Cinquanta. In: Xodo, Carla and Benetton, Mirka (eds.): Emmanuel Mounier. Origini e prospettive della Scuola di pedagogia di Padova. Pensa Multimedia, Lecce.

Zago, Giuseppe (2010): Sessant'anni fa il personalismo a Padova. InAngori Sergio et Alii (eds), Persona e educazione. Studi in onore di S. S. Macchietti. Armando, Roma.

Zizioli, Elena (2009): Luigi Volpicelli: un idealista fuori dalle formule. Anicia, Roma. 